\title{
PENINGKATAN HASIL BELAJAR MATEMATIKA DENGAN MENGGUNAKAN MODEL DIRECT INSTRUCTION
}

\author{
Wiwik Sukrorini \\ Guru Matematika SMP Negeri 23 Pontianak
}

\begin{abstract}
This study was motivated by the study of matter form roots and rank Numbers are still low.Therefore, the teacher will use the Direct Instruction model of which aim to improve student learning outcomes grade IX SMP 23 Pontianak. The subjects were students of grade IX A second semester of 2013/2014. The study lasted for 2 cycles, where in the first cycle showed an average of 71,60 while the learning outcomes in the second cycle, the average results of study show the score 72.14. The mastery learning of students in the first cycle is only $39 \%$ of all student in the class, whereas in the second cycle, mastery learning reaches 57\%.Teacher performance assessment by the observer in the first cycle on average 70.95 and the second cycle averaged 72.28. Thus, learning the Direct Instruction model can improve learning outcomes as well as the percentage of mastery learning. Based on the research results, the learning Mathematics Direct Instruction model can be used as an alternative learning strategies that can be implemented in an effort to improve learning outcame.
\end{abstract}

Keywords: Direct Instruction Model.

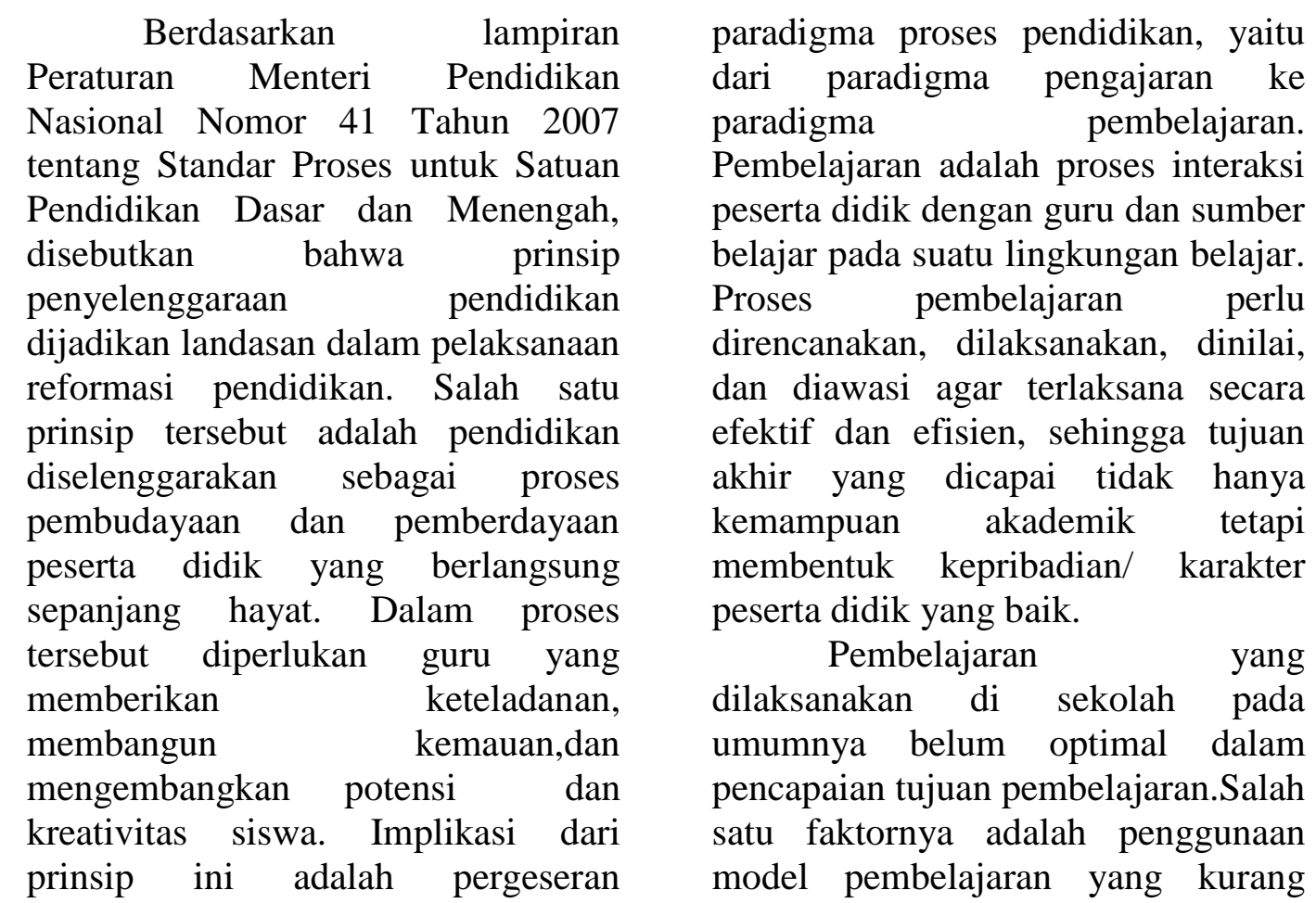


tepat dan bervariasi. Alasannya antara lain: guru tidak mempunyai cukup referensi mengenai beberapa pendekatan atau model pembelajaran matematika yang dapat digunakan, atau guru kurang mampu dalam menggunakan pendekatan atau model pembelajaran matematika, karena waktu terbatas, dan alat pembelajaran yang terbatas.

Berdasarkan data yang di miliki tentang hasil belajar siswa kelas IX D,E,F tentang materi Pokok bahasan bilangan berpangkat, menunjukkan hasil yang kurang memuaskan, karena masih banyak siswa yang belum mencapai KKM. Fakta tersebut disajikan dalam Tabel 1.

Tabel 1 Hasil belajar Materi Bilangan Berpangkat dan Bentuk akar Siswa Kelas IX D, E, F, tahun 2012-2013.

\begin{tabular}{ccccc}
\hline $\begin{array}{c}\text { N } \\
\mathrm{o}\end{array}$ & Kelas & $\begin{array}{c}\text { Rata- } \\
\text { rata }\end{array}$ & Ketuntasan & Keterangan \\
\hline 1 & IX D & 56,79 & $17,85 \%$ & $\begin{array}{c}\text { Tuntas 5 siswa } \\
\text { dari 28 siswa }\end{array}$ \\
\hline 2 & IX E & 65,07 & $46,42 \%$ & $\begin{array}{c}\text { Tuntas 13siswa } \\
\text { dari 28 siswa }\end{array}$ \\
\hline 3 & IX F & 53,44 & $24,14 \%$ & $\begin{array}{c}\text { Tuntas 7siswa } \\
\text { dari 29 siswa }\end{array}$ \\
\hline
\end{tabular}

Selain dari data tersebut, peneliti juga belum pernah mencoba menggunakan Model Direct Instruction dalam mengajarkan materi Bilangan barpangkat dan bentuk akar. Oleh karena itu diperlukan strategi yang tepat agar dapat membantu peningkatan hasil belajar siswa seperti apa yang diharapkan guru.

Dilihat dari konteks perbaikan kualitas pendidikan, maka penggunaan Model Direct Instruction (Pembelajaran Langsung) merupakan salah satu strategi yang dapat digunakan untuk memperbaiki sistem pembelajaran dalam rangka peningkatan hasil belajar siswa. Hal tersebut sesuai dengan pendapat Sudrajat (2009) karena Pembelajaran Langsung memiliki keunggulan yaitu:

1. Dengan model pembelajaran langsung, guru mengendalikan isi materi dan urutan informasi yang diterima oleh siswa sehingga dapat mempertahankan fokus mengenai apa yang harus dicapai oleh siswa.

2. Dapat diterapkan secara efektif dalam kelas yang besar maupun kecil.

3. Dapat digunakan untuk menekankan poin-poin penting atau kesulitan-kesulitan yang mungkin dihadapi siswa sehingga hal-hal tersebut dapat diungkapkan.

4. Dapat menjadi cara yang efektif untuk mengajarkan informasi dan pengetahuan faktual yang sangat terstruktur.

5. Merupakan cara yang paling efektif untuk mengajarkan konsep dan keterampilan-keterampilan yang eksplisit kepada siswa yang berprestasi rendah.

6. Dapat menjadi cara untuk menyampaikan informasi yang banyak dalam waktu yang relatif singkat yang dapat diakses secara setara oleh seluruh siswa, sehingga meningkatkan hasil belajar siswa.

7. Memungkinkan guru untuk menyampaikan ketertarikan pribadi mengenai mata pelajaran (melalui presentasi yang antusias) yang dapat merangsang ketertarikan dan antusias siswa.

Menurut Theresia (2012) model pembelajaran langsung sangat diperlukan dalam pembelajaran mata pelajaran matematika terutama yang terkait dengan membelajarkan operasi 
(aturan pengerjaan hitung, aljabar, matematika, dll.) sementara pada pembelajaran materi bilangan berpangkat dan bentuk akar banyak aturan dalam pengerjaan hitung. Karena itu Peneliti menganggap penggunaan model Direct Instruction kelas IX A SMP Negeri 23 Pontianak, pada materi bilangan berpangkat dan bentuk akar dapat membantu meningkatkan hasil belajar.

Dari uraian diatas peneliti tertarik untuk menggunakan Model Direct Intruction dalam meningkatkan hasil belajar bagi siswa SMP Negeri 23 Pontianak tahun 2013-2014 pada materi bilangan berpangkat dan bentuk akar. Diharapkan dengan menggunakan Model Direct Intruction dapat meningkatkan hasil belajar bagi siswa SMP Negeri 23 Pontianak tahun 2013-2014 pada materi bilangan berpangkat dan bentuk akar. Dalam hal ini, secara khusus peneliti bertujuan untuk mengetahui proses pembelajaran dengan model Direct Instruction pada materi bilangan berpangkat dan bentuk akar siswa kelas IX A SMP Negeri 23 Pontianak tahun pelajaran 2013-2014. Selain itu juga untuk mengetahui hasil belajar siswa kelas IX A SMP Negeri 23 Pontianak tahun pelajaran 2013-2014 pada materi bilangan berpangkat dan bentuk akar.

Manfaat yang diharapkan dari penelitian yang dilakukan ini adalah (1). siswa dapat meningkatan penguasaan materi bilangan berpangkat dan bentuk akar melalui pembelajaran Model Direct Instruction (2) bagi guru ,memberikan pengalaman langsung dalam komparasi model pembelajaran (3) bagi sekolah dapat meningkatkan kompetensi guru dalam pembelajaran khususnya pembelajaran matematika.

Belajar merupakan hal yang dapat dipandang dari dua sisi yaitu sisi siswa dan dari sisi guru. Dari sisi siswa, hasil belajar merupakan tingkat perkembangan mental yang lebih baik bila dibandingkan pada saat sebelum belajar. Tingkat perkembangan mental tersebut terwujud pada jenisjenis ranah kognitif, afektif, dan psikomotor. Sedangkan dari sisi guru, hasil belajar merupakan saat terselesikannya bahan pelajaran. Menurut Hamalik (2001), hasil belajar adalah bila seseorang telah belajar dan terjadi perubahan tingkah laku pada orang tersebut, misalnya dari tidak tahu menjadi tahu, dan dari tidak mengerti menjadi mengerti. Dari penjelasan tersebut dapat disimpulkan bahwa hasil belajar adalah kemampuankemampuan yang dimiliki siswa setelah ia menerima pengalaman belajarnya. Hasil belajar digunakan oleh guru untuk dijadikan ukuran atau kriteria dalam mencapai suatu tujuan pendidikan. Penilaian hasil belajar siswa ditekankan pada praktek pengembangan dan pengetahuan dasar yang sesuai mengukur dengan teliti keterampilan yang sederhana dan keterampilan yang kompleks.

Direct Instruction atau
pembelajaran umumnya dirancang secara khusus untuk mengembangkan aktivitas belajar di pihak siswa berkaitan dengan aspek pengetahuan prosedural serta pengetahuan deklaratif yang terstruktur dengan baik dan dapat dipelajari selangkah demi selangkah. Fokus utama dari pembelajaran ini adalah pelatihan-pelatihan yang dapat diterapkan dari keadaan nyata yang 
sederhana sampai yang lebih kompleks. Menurut Akhmad Sudrajat (2009), model pembelajaran langsung adalah model pembelajaran yang menekankan pada penguasaan konsep dan/atau perubahan perilaku dengan mengutamakan pendekatan deduktif, dengan ciri-ciri sebagai berikut: (1) transformasi dan ketrampilan secara langsung; (2) pembelajaran yang berorientasi pada tujuan tertentu; (3) materi pembelajaran yang telah terstuktur; (4) lingkungan belajar yang telah terstruktur; dan (5) distruktur oleh guru. Sedangkan menurut Indrawati (2005): pembelajaran langsung dapat didefinisikan sebagai model pembelajaran dimana guru mentransformasikan informasi atau keterampilan secara langsung kepada siswa dan pembelajaran berorientasi pada tujuan pembelajaran dan distruktur oleh guru.

Dalam model pembelajaran langsung terdapat dua kegiatan penting dalam pelaksanaannya yaitu :

1. Tugas perencanaan, yaitu memilih isi, melakukan analisis tugas, merumuskan tujuan, merencanakan waktu dan ruang.

2. Tugas-tugas interaktif yaitu suatu kegiatan yang berhubungan dengan pelaksanaan dalam kelas, diantaranya menyampaikan tujuan menyiapkan peserta didik, persentasi dan demonstasi dan menyediakan pelatihan terbimbing.

Menurut Ismail (2003), fase dalam pembelajaran langsung adalah (a) Menyampaikan tujuan dan mempersiapkan siswa (b) Mendemonstrasikan pengetahuan dan keterampilan (c) Membimbing pelatihan (d) Mengecek pemahaman dan memberikan umpan balik (e) Memberikan latihan dan penerapan Langkah-langkah dalam model pembelajaran langsung adalah

1. Langkah awal meliputi guru menyiapkan siswa baik secara psikis dan fisik untuk mengikuti proses pembelajaran, menjelaskan tujuan pembelajaran atau kompetensi dasar yang akan dicapai, mengajukan pertanyaan pertanyaan yang mengaitkan pengetahuan sebelumnya Langkah langkah dengan materi yang akan dipelajari. Langkah awal ini dilakukan untuk memberikan motivasi pada siswa untuk berperan penuh pada proses pembelajaran

2. Langkah berikutnya adalah guru mempresentasikan materi ajar atau mendemonstrasikan mengenai keterampilan tertentu. Selanjutnya guru memberikan kesempatan kepada siswa untuk melakukan latihan dan memberikan umpan balik. Dalam langkah ini dikaitkan guru memfasilitasi siswa untuk mengeksplorasi, mengelaborasi dan mengkonfirmasi proses dari pembelajaran.

3. Langkah akhir adalah guru memberikan latihan untuk menerapkan konsep yang telah dipelajari,membuat rangkuman bersama-sama siswa, melakukan refleksi terhadap pembelajaran yang sudah berlangsung, merencanakan kegiatan tindak lanjutnya, menyampaikan suatu rencana pembelajaran pada pertemuan berikutnya.

Menurut Sudrajat (2009), disarikan dari Depdiknas Modul KKG/MGMP, Model Pembelajaran Langsung merupakan salah satu 
pendekatan mengajar yang dapat membantu siswa mempelajari keterampilan dasar dan memperoleh informasi yang dapat diajarkan bertahap sehingga dapat diambil kesimpulan pembelajaran langsung memiliki kelebihan seperti berikut:

1. Dengan model pembelajaran langsung, guru mengendalikan isi materi dan urutan informasi yang diterima oleh siswa sehingga dapat mempertahankan fokus mengenai apa yang harus dicapai oleh siswa.

2. Dapat diterapkan secara efektif dalam kelas yang besar maupun kecil.

3. Dapat digunakan untuk menekankan hal-hal penting atau kesulitan-kesulitan yang mungkin dihadapi siswa sehingga hal-hal tersebut dapat diungkapkan.

4. Dapat menjadi cara yang efektif untuk mengajarkan informasi dan pengetahuan faktual yang sangat terstruktur.

5. Merupakan cara yang paling efektif untuk mengajarkan konsep dan keterampilan-keterampilan yang eksplisit kepada siswa yang berprestasi rendah.

6. Dapat menjadi cara untukmenyampaikan informasi yang banyak dalam waktu yang relatif singkat dan dapat diakses secara setara oleh seluruh siswa.

7. Memungkinkan guru untuk menyampaikan ketertarikan pribadi mengenai mata pelajaran (melalui presentasi yang antusias) yang dapat merangsang ketertarikan dan antusiasme siswa. Model pembelajaran langsung dapat digunakan untuk membangun model pembelajaran dalam bidang studi tertentu. Guru dapat menunjukkan bagaimana suatu permasalahan dapat didekati, bagaimana informasi dianalisis, dan bagaimana suatu pengetahuan dihasilkan.

8. Pembelajaran yang eksplisit membekali siswa dengan "caracara disipliner dalam memandang dunia (dan) dengan menggunakan perspektif-perspektif alternatif" yang menyadarkan siswa akan keterbatasan perspektif yang inheren dalam pemikiran seharihari.

9. Model Pembelajaran Langsung yang menekankan kegiatan mendengar (misalnya ceramah) dan mengamati (misalnya demonstrasi) dapat membantu siswa yang cocok belajar dengan cara-cara ini.

10. Ceramah dapat bermanfaat untuk menyampaikan pengetahuan yang tidak tersedia secara langsung bagi siswa, termasuk contoh-contoh yang relevan dan hasil-hasil penelitian terkini.

11. Model pembelajaran langsung (terutama demonstrasi) dapat memberi siswa tantangan untuk mempertimbangkan kesenjangan yang terdapat di antara teori (yang seharusnya terjadi) dan observasi (kenyataan yang mereka lihat).

12. Demonstrasi memungkinkan siswa untuk berkonsentrasi pada hasil hasil dari suatu tugas dan bukan teknik-teknik dalam menghasilkan hasilmya. Hal ini penting terutama jika siswa tidak memiliki kepercayaan diri atau keterampilan dalam melakukan tugas tersebut.

13. Siswa yang tidak dapat mengarahkan diri sendiri dapat tetap berprestasi apabila model 
pembelajaran langsung digunakan secara efektif.

14. Model pembelajaran langsung bergantung pada kemampuan refleksi guru sehingga guru dapat terus menerus mengevaluasi dan memperbaikinya.

\section{Metode}

1. Setting Penelitian

Dalam penelitian ini yang menjadi subjek dan Objek penelitian adalah sebagai berikut:

a. Subjek penelitian

Penelitian ini dilaksanakan di SMP Negeri 23 Pontianak pada siswa kelas IX A semester genap tahun pelajaran 2013/2014 yang diajar oleh peneliti, dengan jumlah siswa 28 orang terdiri dari 10 orang siswa laki dan 18 orang siswa perempuan.

b. Objek Penelitian.

Objek penelitian adalah hasil belajar matematika siswa. Sehingga dengan digunakannya model Direct Instruction pada mata pelajaran matematika kelas IX semester genap untuk materi Bilangan berpangkat dan Bentuk Akar.

Standar Kompetensinya adalah Memahami sifat-sifat bilangan berpangkat dan bentuk akar serta penggunaanya dalam pemecahan soal sederhana. Sedangkan Kompetensi Dasarnya yaitu 5.1. Mengidentifikasi sifat-sifat bilangan berpangkat dan bentuk akar dan 5.2. Melakukan operasi aljabar yang melibatkan bilangan berpangkat dan benrtuk akar.

c. Waktu Penelitian.

Penelitian ini dilaksanakan pada semester genap tahun pelajaran 2013/2014, yaitu pada minggu ke-2 bulan Pebruari sampai dengan minggu ke-2 bulan Maret.

2. Prosedur/Rancangan Penelitian.

Dalam penelitian ini, peneliti dibantu oleh observer, guru matematika kelas VII yang berpartisipasi aktif secara langsung dalam proses penelitian dari awal hingga berakhirnya penelitian. Adapun tahap-tahap dalam penelitian ini mencakup (1) perencanaan penelitian (2) tahap pelaksanaan penelitian, dan (3) tahap penyusunan laporan. Penelitian ini dilakukan dalam dua siklus. Pada akhir pembelajaran dan akhir siklus dilakukan refleksi untuk melihat kelemahan-kelemahan yang ditemui untuk menjadi masukan dalam penyempurnaan pelaksanaan tindakan berikutnya.

Secara sederhana prosedur penelitian tindakan ini adalah sebagai berikut :

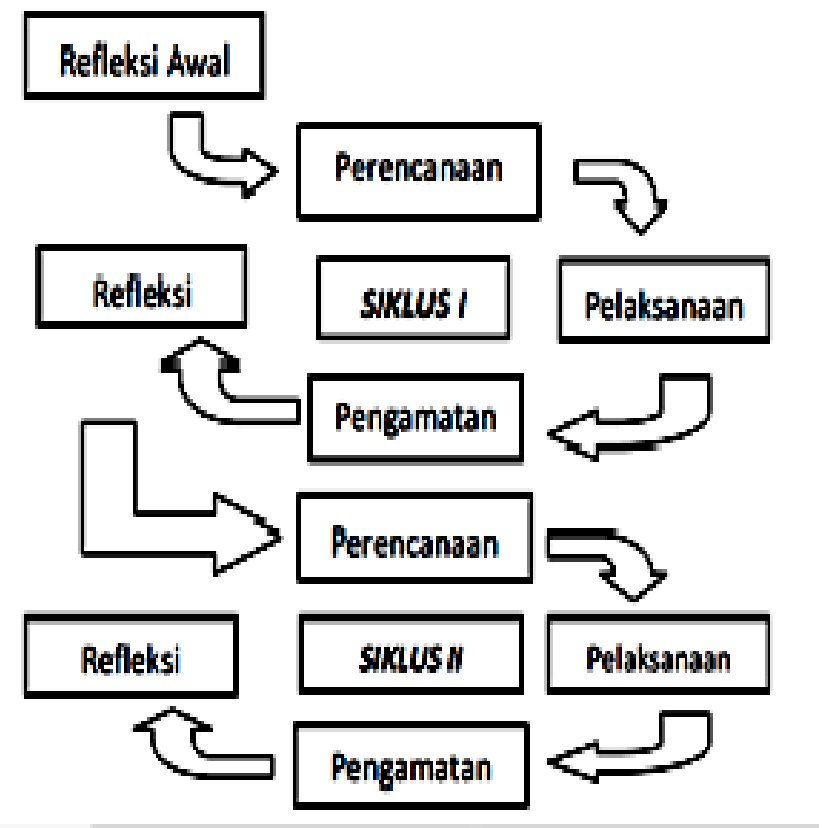

Gambar 1. Siklus PTK 
a. Perencanaan tindakan

Adapun hal-hal yang
dlakukan peneliti pada tahap
perencanaan tindakan adalah
sebagai berikut:

1) Mengadakan pertemuan dengan teman sejawat guru metematika untuk mendiskusikan hal-hal yang berkaitan dengan rencana penelitian antara lain :

a) menetapkan waktu penelitian yaitu sekitar Januari- Maret.

b) menentukan materi penelitian yaitu bilangan berpangkat dan bentuk akar.

c) menetapkan kelas yang menjadi tempat penelitian yaitu kelas IX A.

d) menentukan banyaknya siklus, apabila pada siklus ke-2 sudah mengalami peningkatan hasil belajar, maka penelitian cukup 2 siklus. Tetapi jika pada siklus ke-2 belum mengalami peningkatan hasil belajar, maka penelitian dilanjutkan pada siklus ke-3.

2) Mempersiapkan perangkat pembelajaran antara lain:

a) menyusun silabus,

b) menyusun rencana pelaksanaan pembelajaran (RPP),

c) menyusun kisi-kisi tes

d) membuat soal tes

3) Mempersiapkan lembaran observasi guru. Dalam hal ini peneliti menggunakan lembaran observasi yang baku yang dikeluarkan oleh Fakultas Keguruan dan Ilmu
Pendidikan UNTAN, yang biasa kita kenal dengan nama APKG 2, karena didalam indikator penilaian yang ada di APKG 2, juga memuat fase-fase yang ada di Direct Intraction. Lembaran observasi ini biasa digunakan oleh guru pamong dan dosen pembimbing untuk mengobservasi calon guru dalam kegiatan PPL.

b. Pelaksanaan tindakan.

Dilaksanakan dalam 2 siklus, pada siklus pertama 3 kali pertemuan yaitu tanggal 12, 17 dan 18 Februari 2014. Peneliti melakukan kegiatan sesuai rencana. Materi pembelajarannya pengertian bilangan berpangkat, pangkat sebenarnya dan pangkat tak sebenarnya. Post test siklus I, dilaksanakan pada 19 Februari Sedangkan pada siklus 2 tindakan dilaksanakan pada tanggal 27 Februari, 3 Maret dan 4 Maret dengan materi bilangan pangkat pecahan dan bentuk akar.Post test siklus 2 dilaksanakan pada 5 Maret 2014.

c. Pengamatan tindakan

Selama melaksanakan tindakan, peneliti dibantu teman sejawat sebagai observer. Pengamatan dilakukan dengan berpedoman pada lembaran observasi.

d. Refleksi

Refleksi dilakukan setelah akhir siklus. Peneliti berdiskusi dengan observer mengenai hasil pengamatan selama pembelajaran berlangsung. Dari pengamatan observer, ternyata ada siswa yang tidak teliti didalam penulisan bilangan berpangkat. Dengan 
demikian Peneliti akan memperbaiki pengajaran untuk materi berikutnya, juga akan menertibkan tata tulis bilangan berpangkat.

3. Pengumpulan data

\section{Hasil dan Pembahasan}

1. Siklus 1

Setelah melaksanakan tindakan pada siklus 1 dengan 3 kali pertemuan,kinerja guru yang diamati oleh observer, diperoleh data

Jenis data yang dikumpulkan meliputiedtatgakik umantkatif dan data kualitatif. Data kuantitatifnya yaitu

4. Analisis Data dan Verifikasi.

a. Analisis Data

Setelah siswa mengerjakan tes akhir siklus, lembaran jawaban siswa dikoreksi dengan menggunakan acuan kunci jawaban, dan penilaiannya menggunakan pedoman penilaian. Untuk menyatakan katagori daya serap klasikal dari hasil belajar , dan dianalisis menggunakan kriteria seperti Tabel 2.

Tabel 2. Interval dan Kategori Daya Serap Kelas.

\begin{tabular}{cc}
\hline$\%$ Interval & Kategori \\
\hline $85-100$ & Amat baik \\
\hline $70-84$ & Baik \\
\hline $60-69$ & Cukup \\
\hline$<60$ & Kurang \\
\hline
\end{tabular}

Kemudian dihitung berapa orang yang tuntas, artinya yang nilai hasil belajarnya sama dengan atau melebihi ketuntasan minimal yang telah ditentukan sekolah. Dalam hal ini, untuk mata pelajaran matematika kelas IX, KKM nya adalah 73. Selanjutnya dihitung, berapa persen yang telah tuntas.

b. Verifikasi Data

Untuk menyakinkan data yang sudah didapat,benar-benar valid, maka Peneliti melakukan verifikasi data dengan cara mengoreksi ulang jawaban siswa. Hasil verifikasi ternyata tidak ada perbedaan nilai siswa pada pengoreksian pertama.
Tabel 3. Penilaian Kinerja Guru

Siklus I.

\begin{tabular}{ccccc}
\hline \multicolumn{5}{c}{ Pertemuan } \\
\hline & 1 & 2 & 3 & $\begin{array}{c}\text { Rata- } \\
\text { rata }\end{array}$ \\
\hline $\begin{array}{c}\text { Penilaian } \\
\text { Kinerja } \\
\text { Guru }\end{array}$ & 66,43 & 74,29 & 72,14 & 70,95 \\
\hline
\end{tabular}

Dipertemuan ke-4, peneliti mengadakan tes akhir siklus. Bentuk tesnya adalah soal essay sebanyak 5 soal.

Tabel 4. Hasil Tes Akhir Siklus 1.

\begin{tabular}{llc}
\hline No & Komponen & Hasil \\
\hline 1 & Nilai tertinggi & 95 \\
\hline 2 & Nilai terendah & 35 \\
\hline 3 & Rata-rata & 71,60 \\
\hline
\end{tabular}

Pada akhir siklus 1, siswa yang mengikuti tes sebanyak 30 orang dan yang dapat memenuhi nilai ketuntasan minimal hanya 11 orang atau hanya $39 \%$ saja. Dalam hal ini ketuntasan minimal adalah nilai 73 .

\section{Siklus 2}

Pada siklus 2 dengan 3 kali pertemuan kinerja guru yang diamati oleh observer, tertuang dalam tabel berikut:

Tabel 5. Penilaian Kinerja Guru Siklus II.

\begin{tabular}{ccccc}
\hline \multicolumn{5}{c}{ Pertemuan } \\
\hline & 7 & 8 & 9 & $\begin{array}{c}\text { Rata- } \\
\text { rata }\end{array}$ \\
\hline $\begin{array}{c}\text { Penilaian } \\
\text { Kinerja } \\
\text { Guru }\end{array}$ & 67,86 & 72,14 & 77,14 & 72,28 \\
\hline
\end{tabular}


Diakhir siklus 2, diadakan tes untuk melihat hasil belajar siswa, yang terangkum dalam tabel berikut:

Tabel 6. Hasil Tes Akhir Siklus 2.

\begin{tabular}{lll}
\hline No & Komponen & Hasil \\
\hline 1 & Nilai tetinggi & 100 \\
\hline 2 & Nilai terendah & 45 \\
\hline 3 & Rata-rata & 72,14 \\
\hline
\end{tabular}

Pada akhir siklus 2, siswa yang dapat mencapai ketuntasan ada 18 orang atau $57 \%$ dari seluruh siswa yang berjumlah 30 orang. Dilihat dari hasil pekerjaan siswa dalam menjawab soal test, ternyata masih terdapat siswa yang belum menguasai faktor persekutuan dan masih belum tertib didalam penulisan bilangan yang bertanda akar. Namun dilihat dari hasil belajar di siklus 2, dapat disimpulkan ada peningkatan jumlah siswa yang tuntas, di siklus 1 hanya 11 orang ,sedangkan di siklus 2 ada 18 orang yang tuntas, dengan demikian ada peningkatan sebanyak 7 orang. Jika diprosentasekan, ketuntasan pada siklus 1 adalah $39 \%$ dan di siklus 2 adalah $57 \%$, dengan demikian ada peningkatan sebesar 16 $\%$. Dilihat dari daya serapnya, pada siklus 1 mencapai $72 \%$ dan di siklus 2 juga $72 \%$, hal ini masuk dalam interval $70-84$ dan dapat dikatagorikan "baik"

$$
\text { Untuk lebih jelasnya }
$$

peningkatan hasil belajar tersebut, disajikan dalam bentuk diagram batang pada Gambar 2 .

Dari hasil pengamatan observer, pada data yang tersaji pada Tabel 3 dan 5 dirangkum pada Tabel 7. Berdasarkan Tabel 7, terlihat bahwa penilaian kinerja guru ada peningkatan sebesar $(72-71)=1$. Untuk lebih jelasnya peningkatan penilaian kinerja guru tersebut, disajikan dalam bentuk diagram batang Gambar 3 .

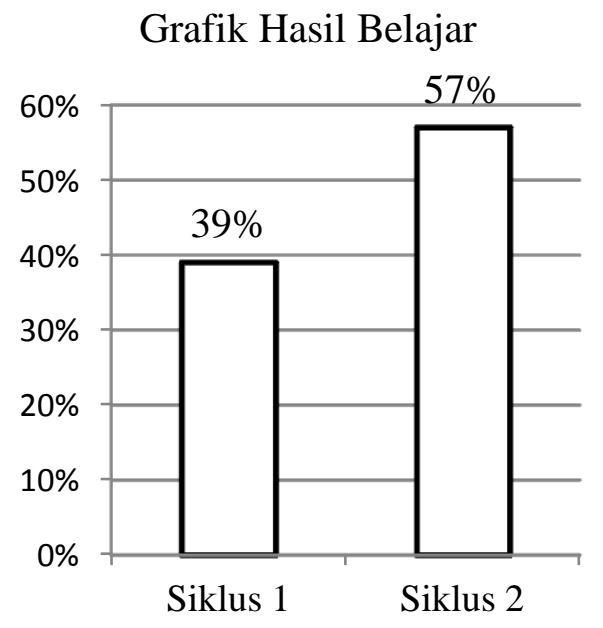

Gambar 2. Peningkatan hasil belajar siswa siklus 1 dan siklus 2 .

Tabel 7. Penilaian Kinerja Guru

\begin{tabular}{ccc}
\hline & $\begin{array}{c}\text { Rerata } \\
\text { siklus 1 }\end{array}$ & $\begin{array}{c}\text { Rerata } \\
\text { siklus 2 }\end{array}$ \\
\hline $\begin{array}{c}\text { Penilaian } \\
\text { Kinerja } \\
\text { Guru }\end{array}$ & $70,95=71$ & $72,28=72$ \\
\hline
\end{tabular}

\section{Grafik Kinerja Guru}

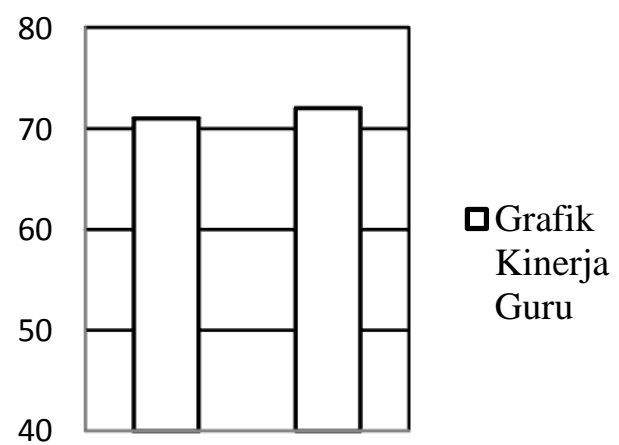

Siklus $1 \quad$ Siklus 2

Gambar 3. Kinerja guru pada siklus 1 dan siklus 2 .

\section{Simpulan dan Saran}

Dari keseluruhan uraian termasuk pembahasan terhadap hasil yang diperoleh pada siklus I dan 
siklus II, dapat disampaikan simpulkan sebagai berikut:

1. Proses pembelajaran dengan model Direct Instruction menunjukkan bahwa daya serap siswa pada siklus I dan siklus II mencapai 72 $\%$, hal ini dapat dikatagorikan "baik".

2. Ketuntasan hasil belajar siswa kelas IX A SMP Negeri 23 Pontianak tahun pelajaran 20132014 pada materi bilangan berpangkat dan bentuk akar mengalami peningkatan, karena pada siklus I ketuntasan belajar sebanyak $39 \%$ dari jumlah seluruh siswa, sedangkan pada siklus II ketuntasannya mencapai $57 \%$, dengan demikian mengalami peningkatan sebesar $16 \%$.

Saran:

1. Kepada teman-teman sejawat (guru Matematika SMP) dalam pembelajaran Bilangan berpangkat dan bentuk akar dapat menggunakan model Direct Instruction, karena model ini dapat meningkatkan hasil belajar.

2. Untuk dapat menghasilkan peningkatan yang lebih baik, disarankan kepada teman-teman guru agar mempersiapkan perencanaan yang matang dan pelaksanaan yang sungguhsungguh.

\section{Daftar Rujukan}

Depdiknas. (2003). Undang-Undang RI Nomor 20 Tahun 2003 tentang Sistem Pendidikan Nasional. Jakarta: Depdiknas. (2006). Peraturan Menteri Pendidikan Nasional RI Nomor 22 Tahun 2006 tentang Standar Isi untuk Satuan Pendidikan
Dasar Dan Menengah. Jakarta: Depdiknas.

(2007). Peraturan Menteri

Pendidikan Nasional RI Nomor

41 Tahun 2007 tentang

Standar Isi. Jakarta: Depdiknas.

Hamalik Oemar. (2001).

Perencanaan Pengajaran

Berdasarkan Pendekatan

Sistem, Bumi Aksara, Bandung.

http://akhmadsudrajat.wordpress.com/ 2011/01/27/model-pembelajaran-langsung/ (diakses 21-122013)

Indrawati. (2005). Model Pembelajaran Langsung, PPPG IPA, Bandung Depdiknas.
Ismail(2003). Model -model Pembelajarsn. Jakarta. Direktorat PLP

Kemendiknas. (2011). Penyusunan Laporan Penelitian Tindakan Kelas Mata Pelajaran Matematika SMP, P4TK, Yogjakarta

Sudrajad (2009), Modul KKG/MGMP Model Pembelajaran Langsung, P4TK, Yogjakarta, Depdiknas

$\begin{array}{cr}\text { Theresia Widyatini } & \text {.(2012). } \\ \text { Penerapan Model } \\ \text { Pembelajaran } & \text { Langsung } \\ \text { Dalam mata pelajaran } \\ \text { matematika SMP/Mts, PPPPTK } \\ \text { Matematika, Yogjakarta. }\end{array}$

